\title{
A Review of the UK's Tourism Recovery Plans Post COVID-19
}

\begin{abstract}
By Peter Jones*
The COVID-19 pandemic has wreaked global economic havoc and disrupted the lives of the majority of the world's population, and many governments have pursued a wide range of measures to stimulate economic and social recovery. In June 2021 the UK government published a tourism recovery plan, which set out the role that it hopes to play in assisting and accelerating the tourism sector's recovery from COVID-19 and a framework for how the government will work with the sector to rebuild and revitalise tourism within the UK. This paper focuses on this plan, and includes a short literature review, a summary of the plan, and some concluding reflections.
\end{abstract}

Keywords: COVID-19, recovery plan, tourism sector, UK government

\section{Introduction}

The COVID-19 pandemic has wreaked global economic havoc and disrupted the lives of the majority of the world's population, and many governments have pursued a wide range of measures to stimulate economic and social recovery. The tourism industry has been particularly severely hit by the pandemic, and the United Nations World Tourist Organisation (2021), for example, argued that "tourism is one of the sectors most affected by the COVID-19 pandemic, impacting economies, livelihoods, public services and opportunities on all continents", and that "all parts of its vast value-chain have been affected". In a similar vein, Pangetsu (2021) argued that "tourism is among the industries that have been hit hardest by the COVID-19 crisis", that "over a year since the onset of the pandemic, the numbers are staggering: Tourism destinations recorded one billion fewer international arrivals in 2020 than in 2019", and that "100 to 120 million tourism jobs were put at risk, a large proportion in small and medium-sized enterprises". At the national level, governments have looked to boost their nations' tourist industries, on the one hand by economy-wide stimulus packages, and on the other by tourism specific measures. A number of European governments including Spain, Ireland, Greece, and the Netherlands have introduced tourism recovery plans, designed to build a more resilient tourist economy post COVID-19.

Tourism is a major element in the UK's economy, it includes tourist visitors from other countries and domestic tourism, and it embraces a wide variety of activities and business enterprises including international, national and local travel, hotel and accommodation services, food and beverages, sport and recreational activity, tourism attractions and products, exhibitions, conferences, cultural activities, and a wide range of retail outlets. The COVID-19 pandemic severely

\footnotetext{
*Associate Professor, School of Business, University of Gloucestershire, UK.
} 
affected all the elements of the UK's tourism industry, not least because of the range of government measures to tackle the spread of the virus, including the introduction of restrictions on overseas travel, of social distancing and lockdown, and of the closure of a number of types of shops and hospitality venues, and also because of many people's reluctance to travel. By way of two summary illustrations, the Office for National Statistics (2021) estimated that overseas residents made $73 \%$ less visits to the UK in 2020 than in 2019, and Visit Britain Visit England (2021) estimated that domestic tourist spending in 2020 was $63 \%$ lower than in 2019.

The UK Government has pursued a wide range of measures to support the tourism, hospitality and leisure industries. In producing a briefing on the impact of the COVID-19 pandemic on the tourist industry for the House of Lords, Newson (2021), for example, catalogued a range of measures including, £12 billion from the COVID-19 job retention scheme, $£ 5$ billion in bounceback loans, a temporary reduction in Value Added Tax for hospitality, accommodation and attractions, funding to support communities that depend heavily on tourism, and funding to help destination management organisations deemed to be at severe risk of closure. More strategically, in June 2021, the UK Government published "The Tourism Recovery Plan" (Department for Digital, Culture, Media \& Sport 2021). This plan "sets out the role that the UK government will play in assisting and accelerating the tourism sector's recovery from COVD-19", and "it also sets out a framework for how the government will work with the sector to build back better" (Department for Digital, Culture, Media \& Sport 2021).

\section{Literature Review}

The COVID-19 pandemic has, without doubt, been the biggest, and the most damaging, issue for the tourist industry in the past two years and, not surprisingly, plans, initiatives, and strategies designed to respond to the pandemic, and to support the recovery of the tourism industry have attracted considerable attention in the academic hospitality literature. The aim here is to offer some illustrative examples of this literature, to reference and provide some academic context for this paper. Sharma et al. (2021), for example, proposed a resilience-based framework for reviving the global tourism industry post COVID-19. More specifically, this framework outlined "four prominent factors for building resilience in the industry", namely "government response, technology innovation, local belongingness, and consumer and employee confidence", and Sharma et al. (2021) rather optimistically argued that by that using such inclusive resilience, "the tourism industry may transform into a new global economic order characterized by sustainable tourism, society's well-being, climate action, and the involvement of local communities".

Sigala (2020) reviewed past and emerging literature in an attempt to better help professionals and researchers understand, manage, and valorize both the tourism impacts and the transformational affordance of COVID-19. In conclusion Sigala (2020) argued that the COVID-19 pandemic has created a fertile new context that could stimulate research which may have valuable end-user benefits. 
A wide range of transformational opportunities are identified, including developing greater understanding of how the attitudes of tourists that have been exposed to their own, or others', COVID-19 travel traumas, may influence future travel attitudes and intentions, and may also help the tourism industry to reimagine and create an operating environment that is human-centred and that incorporates sustainability and well-being values.

Kuscer et al. (2021) looked to explore how different countries and destinations responded to the initial impact of the COVID-19 pandemic, in the belief that such an approach might help in choosing the right path by addressing the negative, and taking advantage of the positive, repercussions. The research emphasised the importance not only of government interventions and stimulus packages for destinations to enable them to tackle the COVID-19 crisis, but also of developing resilience and sustainability as integral elements in recovery strategies. Further, it was argued that resilience management can only be developed using a participative process that involves all stakeholders, and that enhancements in destination-wide management of employees, quality management, digitalisation, internal communication, and support for tourism businesses, are all essential in developing resilient tourism destinations.

Pardo and Ladeiras (2020) employed a series of virtual forums to explore the perceptions of travel and tourism experts, drawn from across the globe, of how the COVID-19 pandemic was influencing regional or national tourism activity, and of how they were preparing for the recovery of tourism. The authors identified a number of pillars that should be a priority for tourism authorities, including smart specialisation, enhanced tourism intelligence, new governance, digital skills, and greater cooperation. In addressing smart specialisation, for example, Pardo and Ladeiras (2020) argued that while cultural and natural resources are unique elements with the potential to attract visitors, in an increasingly competitive tourism market, it will be necessary to design and introduce novel experiences, and that investing in smart specialisation in tourism makes sound economic sense. Here the argument is that differentiation comes from unique, authentic, indigenous resources, ideally, exclusive to a particular area, where they can be a more permanent contributory factor to long-term tourism success.

Khalid et al. (2021) investigated if the size of a country's tourism sector influenced the economic policy response to the COVID-19 pandemic, and their findings revealed that the more important the tourism sector, the larger the economic stimulus package introduced by governments. Further, the authors suggested that a more targeted economic package may be required in countries where the travel and tourism sector is an major part of the overall economy, and argued that such countries should look to support the domestic tourism sector, to serve as a buffer for the industry as a whole, because it will easier to kick start compared to the international tourism sector.

Some of the research on responses to the COVID-19 pandemic has focused on specific countries, but a number of general implications can often be identified. Collins- Kreiner and Ram (2021), for example, looked to outline national COVID19 exit strategies and to analyse recovery strategies in seven countries, namely Australia, Austria, Brazil, China, Israel, Italy and Japan. The authors concluded 
that all counties were implementing tactical measures to contend with the crisis as part of their national tourism policies, but that there was little evidence that countries had formalised comprehensive exit strategies and plans for the tourism sector. At the same time, Collins-Kreiner and Ram (2021) also emphasised that no single policy or strategy is appropriate for all countries. While this is seen to be understandable in that each country has its own unique set of tourism attractions, and in that the pandemic has affected different countries in different ways, the authors argued that without international commitment to sustainable tourism, the sector will not become more resilient and better prepared for future crises.

Zhang et al. (2021) argued that the effect of the COVD-19 pandemic had rendered forecasts of tourism demand in Hong Kong obsolete, but that such forecasting was a fundamental step in the recovery process, as it informs decisions about the appropriate phases of action. With this in mind, they explored combining econometric and judgmental methods to forecast possible paths to tourism recovery. More specifically, the authors used autoregressive correction models to generate baseline forecasts, and Delphi adjustments to evaluate the economic effects of the pandemic on the tourism industry. In outlining the implications of their work, Zhang et al. (2021) suggested that due to the uncertainty and volatility of the COVID-19 pandemic, tourism recovery should involve a gradual process and the rebranding of destination imagery would be a critical factor in domestic and short-haul market recovery.

Rogerson and Rogerson (2021) recognised that the tourism sector in South Africa had experienced the scale and the devastating impact of the COVID-19 pandemic, that this would reshape existing patterns of tourism, and that understanding these changes was essential in designing appropriate policy interventions. The authors stressed the importance of domestic tourism in the recovery process and here, and by way of conclusion, they made a number of recommendations. They argued, for example, that there were opportunities not only to address the uneven geographical spread of tourism, because in the wake of COVID-19, many tourists would seek out less crowded places, but also to market natural open space, tranquillity, and seclusion to potential domestic tourists.

\section{Planning for Recovery}

In introducing the framework for "The Tourism Recovery Plan", the UK government rightly recognised that "COVID-19 will continue to present challenges and uncertainties to the tourism sector for some time", but that it "wants to see a growing, dynamic and sustainable tourism sector reaching its full potential and driving growth in every nation and region of the UK" (Department for Digital, Culture, Media \& Sport 2021). By way of introduction, the plan emphasised that the UK's tourist industry was a national asset, that the UK was a world leading tourist destination, and that an important part of the UK's attraction was that it had something for everyone. At the same time, the government also recognised that the UK's tourist industry must be seen in its wider international context and that in the 
wake of the COVID-19 pandemic, attracting tourists back and retaining tourist markets, will be fiercely competitive.

The government's goal in drawing up its tourism recovery plan is "to build on the UK's position as one of the most effective tourist destinations in the world and to enhance the UK's offer even further by effectively showcasing and marketing the country's tourist assets" (Department for Digital, Culture, Media \& Sport 2021). This overall goal was distilled down into a number of short to medium term objectives, which included to help to see a swift return to 2019 levels of tourism activity and visitor expenditure, the sharing of tourism benefits to all parts of the UK, a tourism industry that contributes to the enhancement and conservation of the country's cultural, natural and historic heritage, a tourism industry that is inclusive and accessible to all, and for the UK to be the leading European nation for hosting business exhibitions and conferences.

These objectives are certainly ambitious and there is an explicit recognition that they will not be achieved overnight, and that, as such, the plan is seen as the first steps towards recovery. Here the first priorities are to reopen safely and profitably, by taking "a scientific and evidence-based approach to restarting both business tourism and inbound/domestic tourism"; to support businesses; and to stimulate demand (Department for Digital, Culture, Media \& Sport 2021). Here, the government recognises the importance of working in partnership both across government departments and with a wide range of private sector organisations, and argues that the British Tourist Authority and the National Tourism Board will lead much of the recovery.

Stimulating demand is identified as a major challenge, and while there is a clear recognition not only that demand has been artificially suppressed by restrictions put in place in an attempt to control the virus, but also that many people have become risk averse to protect themselves and others. On the domestic side, the plan catalogued a number of financial packages, including a $£ 5$ million marketing campaign, $£ 10$ million for the British Tourist Authority to deliver consumer promotions to support the tourism industry, a scheme to pursue the development of domestic rail tourism, and the launch of a refreshed version of the Countryside Code to encourage people to enjoy the countryside safely and respectfully. The recovery plan also emphasises the need to drive demand back to large cities, such as Manchester and Coventry and also on supporting recovery in London.

The plan acknowledges the vital role that international tourism will have to play in tourism recovery, but it also suggests that the return of inbound tourism will be slower than that of domestic tourism, and that the competition for inbound tourism will be fierce. While the government argues that the success of its vaccine programme will provide a competitive advantage, the plan lists a number of initiatives designed to consolidate that advantage. Here, marketing campaigns will look not only to respond to changes in consumer behavior in the wake of the pandemic, not least the perceived demand for experiential travel, but also to ensure that the UK is well represented overseas. At the same time, the government affirmed its commitment to support the country's assets that draw in both 
international and domestic tourists in new ways, for example, by raising awareness of the rich variety of food and drink cultures throughout the UK.

In addressing "Building Back Better", the recovery plan sets out "how the UK government will work with and support the tourism sector to build back better from this pandemic", and here the emphasis is a "more innovative, data-driven, accessible and resilient tourism -with less reliance on the peak season" and on developing "a thriving tourism sector which is able to attract, train and retain a more skilled workforce all year round" (Department for Digital, Culture, Media and Sport 2021). Geographically, the government is looking to spread the benefits of tourism development throughout the UK, and particularly to less well-known attractions and destinations.

More specifically the recovery plan emphasises the importance of investing in local visitor economies, of having a solid structural foundation for tourism, and of the importance of investing in transport to underpin the country's tourism industry. In addressing investment in local visitor economies, a wide variety of existing funding sources, including support packages both for towns and their High Streets, for community renewal, and for coastal communities, were cataloged in the recovery plan. The plan also stresses the importance of having a solid foundation for tourism and reported that work was underway on the best way to structure and support Destination Management Organisations supporting, and driving, local, regional and national tourism in England. This review reported in August 2021 (de Bois 2021) and made a number of recommendations to support Destination Management Organisations undertaking a wide range of activities that combine "to ensure their destination remains sustainable, competitive and compelling".

Transport is highlighted as having a vital role to play in underpinning the success of the tourism industry. Here, the recovery plan reports that the government is working on a strategic framework for the aviation sector, which will include consideration of the workforce, skills, regional connectivity, regulation, consumers, and a number of environmental issues, while looking to ensure that growth is consistent with the UK's carbon budget and with targets for carbon dioxide emissions. The plan also catalogues its continuing investment in the UK's rail network and emphasises the importance of developing a national bus strategy and promoting such services to visitors, and reported that the government would look to work with tourist bodies and coach operators to facilitate and improve coach access to tourist destinations.

As part of its approach to building back better, the recovery plan also emphasises the importance innovation, resilience, sustainability and inclusivity. Innovation is seen to be vitally important in continuing to embrace the opportunities provided by developments in digital technology. Such developments may, for example, look to build on the virtual and augmented reality tourism and visitor experiences pioneered during lockdown in 2019 and 2020, and may prove vitally important in marketing a wide range of tourism attractions and destinations. In arguing that "protecting and enhancing the environment is at the heart of this government's agenda", the recovery plan suggests that tourism must play its part in "the overall sustainability agenda", which "means pursuing a tourism industry that contributes to the enhancement and conservation of cultural, natural and 
historic heritage and minimises damage to the environment" (Department for Digital, Culture, Media \& Sport 2021). The plan also argues that an inclusive and accessible tourism industry, that meets the needs of a wide range of consumers, is good for business and for people.

\section{Concluding Reflections}

A number of concluding reflections merit attention. In the face of the continuing unpredictability of the future of the COVID-19 pandemic, planning for the recovery of the tourism sector, poses a complex series of challenges for the UK government. On the one hand, the pandemic has caused a major global economic crisis which continues to pose a wide range of seemingly growing problems for the tourism industry. On the other hand, the diversity of the tourism industry means that recovery planning must address a wide range of issues. That said, the government has committed itself to work collaboratively with a wide range of stakeholders to achieve the ambitious goal of helping the tourism industry to recover as quickly as possible, with a return to pre-COVID-19 numbers as soon as possible. While the recovery plan is clearly specific to the UK, it can also be seen to provide a template against which to view government plans for the recovery of tourism in other countries.

That said, perhaps reassuringly, the UK's recovery plan mirrors a number of the themes raised earlier in the literature review, and that in turn provides some sense of general academic, and more specific policy, consensus on planning for the future of the UK tourism industry in the wake of the COVID-19 pandemic. Pardo and Ladeiras' (2020) emphasis on the importance of tourism intelligence, digital skills, and greater cooperation, for example, are certainly reflected in the UK's recovery plan, as is, the focus on the importance of government response, technology innovation, and local ownership, in Sharma et al.'s (2021) framework for reviving the tourism industry.

More specifically, sustainability, an important theme in the UK's recovery plan, is consistently stressed in the academic literature. As, for example, in Sharma et al.'s (2021) assertion that the tourism industry will increasingly be characterised by sustainable tourism. In a similar vein, there is Sigala's (2020) belief that the transformational opportunities effectively presented by the pandemic will create an operating environment for tourism that incorporates sustainability. At the same time, while Kuscer et al.'s (2021) work emphasised the importance of government interventions and stimulus packages in helping the tourism industry to tackle the COVID-19 crisis, they also saw sustainability and resilience as integral to recovery strategies. Collins-Kreiner and Ram's (2021) assertion that without a commitment to sustainable tourism the sector will not become more resilient and better prepared for future crises, also resonates. However, by way of a note of caution, Pardo and Ladeiras (2020), suggested that at that time, no single government had prioritised environmentally, socially or economically sustainable efforts

As such, the UK government's commitment to develop a sustainable tourism sector, might be seen to merit further attention. Here, there are initial issues in that 
sustainable development is a contested concept which means different things to different people. While the most common definition of sustainable development is "development that meets the needs of the present without compromising the ability of future generations to meet their own needs" (World Commission on Environment and Development, 1987), there are a variety of definitions of sustainable development. There are, for example, definitions based in ecology, and there are broader definitions, which embrace economic social and environmental goals. At the same time, a conceptual distinction is often made between weak and strong sustainability. Here, Roper (2012), for example, suggested that the former gives priority to economic growth while the latter recognises the environmental limits to such growth and argued that "strong sustainability subordinates economies to the natural environment and society". On the one hand, the UK's tourism recovery plan looks to accommodate economic and social, as well as environmental, objectives under its sustainability umbrella, without any explicit recognition, for example, that protecting the physical environment may be at odds with the goal of economic growth. On the other hand, the recovery plan would seem consistent with the weak, rather than strong, characterisation of sustainability, in that it privileges economic recovery, and renewed economic growth, over the enhancement and conservation of natural capital.

More generally, and more fundamentally, Cohen (2020) claimed that the COVID-19 crisis offered an important opportunity to step back from the pursuit of conspicuous consumption, and the increasing depletion of the earth's finite resources, on which such patterns of consumption ultimately depend. Further, Cohen (2020) emphasised the importance of looking to ensure that the COVID-19 pandemic both informs, and contributes to, policies designed to promote the transition to more sustainable patterns of consumption. Any such transition would see the leading players, perhaps the majority of the players, within the tourism industry making major changes to their traditional business models, often built around the virtually unregulated use of natural resources, high volumes of visitors, and low cost labour. However, in spite of the severity of the COVID-19 crisis, there is little evidence that the UK government, the leading players within its tourism industry, or the vast majority of consumers, genuinely have the enthusiasm to pursue this transition.

\section{References}

Cohen MJ (2020) Does the COVID-10 outbreak mark the onset of a sustainable consumption transition? Sustainability, Science, Politics and Policy 16(1): 1-3.

Collins-Kreiner N, Ram Y (2021) National tourism strategies during the COVID-19 pandemic. Annals of Tourism Research 89(C): 103076.

de Bois N (2021) The de Bois review; an independent review of destination management organisations in England. UK: Department for Digital, Culture, Media \& Sport. Retrieved from: https://www.visitbritain.org/de-bois-review-independent-reviewdestination-management-organisations-england-published. [Accessed 20 September 2021] 
Department for Digital, Culture, Media \& Sport (2021) The Tourism Recovery Plan. UK: Department for Digital, Culture, Media \& Sport. Retrieved from: https://assets.Pub lishing.service.gov.uk/government/uploads/system/uploads/attachment_data/file/992 974/Tourism_Recovery_Plan_Web_Accessible_.pdf. [Accessed 9 September 2021]

Khalid U, Okafor KE, Burzynska K (2021) Does the size of the tourism sector influence the economic policy response to the COVID-19 pandemic? Current Issues in Tourism. 24(19): 2801-2820.

Kuscer K, Eichelberger S, Petts M (2021) Tourism organizations' responses to the COVID-19 pandemic: an investigation of the lockdown period. Current Issues in Tourism (May).

Newson N (2021) Promoting tourism in the UK. UK Parliament. Retrieved from: https:// lordslibrary.par liament.uk/promoting-tourism-in-the-uk/. [Accessed 17 September 2021]

Office for National Statistics (2021) Overseas travel and tourism 2020. Office for National Statistics. Retrieved from: https://www.ons.gov.uk/peoplepopulationandcommunity/ leisureandtourism/articles/overseastravelandtourism2020/2021-05-24. [Accessed 17 September 2021]

Pangestu ME (2021, Aril 30) Tourism in the post-COVID world: three steps to build better forward. World Bank Blogs. Retrieved from: https://blogs.worldbank.org/voices/tou rism-post-covid-worl d-three-steps-build-better-forward. [Accessed 16 September 2021]

Pardo C, Ladeiras A (2020) COVID-19 "tourism in flight mode": a lost opportunity to rethink tourism - Towards a more sustainable and inclusive society. Worldwide Hospitality Tourism Themes 12(6): 671-678.

Rogerson CM, Rogerson JM (2021) COVID-19 and changing tourism demand: research review and policy implications for South Africa. African Journal of Hospitality, Tourism and Leisure 10(1): 1-21.

Roper J (2012) Environmental risk, sustainability discourses and public relations. Public Relations Inquiry 1(1): 69-87.

Sharma GD, Thomas A, Paul J (2021) Reviving tourism industry: a resilience-based framework. Tourism Management Perspectives 37(Jan): 100786.

Sigala M (2020) Tourism and COVID-19: impacts and implications for resetting industry and research. Journal of Business Research 117(Sep): 312-321.

United Nations World Tourism Organization (2021) Secretary general's policy brief on tourism and COVID-19. United Nations World Tourism Organization. Retrieved from: https://www.unwto.org/tourism-and-covid-19-unprecedented-economic-impacts.

[Accessed 16 September 2021]

Visit Britain Visit England (2021) 2021 Tourism forecast. Visit Britain Visit England. Retrieved from: https://www.vi sitbritain.org/2021-tourism-forecast. [Accessed 17 September 2021]

World Commission on Environment and Development (1987) Our common future. World Commission on Environment and Development. Retrieved from: https://sustainable development.un.org/content/documents/5987our-common-future.pdf. [Accessed 23 September 2021]

Zhang H, Song H, Wen L, Liu C (2021) Forecasting tourism recovery amid COVID-19. Annals of Tourism Research 87(Mar): 103149. 
